\title{
Low-Cycle Fatigue Behavior of Al-4.5Cu-0.6Mg-0.3Si Alloy Containing 0.3\%Ce
}

\author{
Wang Chuan, Wang Jun, Zhang Weida \\ Shenyang Aerospace Xinguang Group Co, Ltd Shenyang, \\ China \\ e-mail: wangc1101@126.com
}

\author{
Che Xin \\ School of Materials Science and Engineering \\ Shenyang University of Technology \\ Shenyang, China \\ e-mail:xiaoxin2004068@163.com
}

\begin{abstract}
Fatigue test of $\mathrm{Al}-4.5 \mathrm{Cu}-0.6 \mathrm{Mg}-0.3 \mathrm{Si}-(0.3 \mathrm{Ce})$ alloy with solution plus artificial aging treatment state was carried out on fatigue experimental machine. The low cycle fatigue behavior and fracture behavior of $\mathrm{Al}-4.5 \mathrm{Cu}-0.6 \mathrm{Mg}-$ 0.3Si-(0.3Ce) alloys were studied. The results show that Al4.5Cu-0.6Mg-0.3Si-(0.3Ce) alloy can exhibit the cyclic hardening, softening and stable cyclic stress response which mainly depends on the imposed total strain amplitudes. The addition of rare earth element $\mathrm{Ce}$ can effectively enhance the cyclic deformation resistance and low-cycle fatigue life of Al4.5Cu-0.6Mg-0.3Si alloy. For the Al-4.5Cu-0.6Mg-0.3Si (0.3Ce) alloy, the relation between plastic and reversals to failure as well as elastic strain amplitudes can be described respectively by Coffin-Manson and Basquin equations. The observations on fracture surfaces reveal that under lowcycle fatigue loading condition, the fatigue cracks initiate transgranular at the surface of fatigue samples and propagate transgranular for the $\mathrm{Al}-4.5 \mathrm{Cu}-0.6 \mathrm{Mg}-0.3 \mathrm{Si}$ (0.3Ce) alloy.
\end{abstract}

$$
\text { Keywords-l-4.5Cu-0.6Mg-0.3Si-(0.3Ce) alloy; at }
$$
treatment; low-cycle fatigue; fatigue fracture

\section{INTRODUCTION}

Fatigue behavior of aluminum alloy research has made great progress as an important part in the field of materials science [1-3]. Many scientific research on the fatigue performance have been done due to the fatigue property of aluminum alloy is closely linked with the practical application [4-6]. It was reported that the Al-Cu$\mathrm{Mg}$ alloy has a higher fatigue crack growth resistance in electric field. Rare earths in non-ferrous metal materials, especially in the application of aluminum and its alloy has made obvious effect, brought a certain economic and social benefits [7]. Rare earth elements can through with the solution of pests to take all kinds of stable compounds, reducing inclusions in aluminum liquid, at the same time reduce the rate of pinhole and the porosity of castings, purification of aluminum alloy [8]. In pursuit of developing high strength aluminum alloys, microalloying of rare earth elements have shown remarkable effect in terms of refining as microstructure, retarding recrystallisation and refining precipitate phases [9-11]. It was reported that when adding $0.3 \% \mathrm{Ce}$, the dislocation and dislocation of aluminium alloy after casting tangles structure lead to changeing the position of crack initiation and extension path, to improve the toughness of the alloy [12]. The role of fining grains of $\mathrm{Ce}$ in addition to the metamorphism of rare earth can also be explained as follows: Main enrichment of $\mathrm{Ce}$ on the grain boundary, or in small rare earth compounds present in the intracrystalline which can be used as the core of heterogeneous nucleation. Therefore, adding trace amounts of $\mathrm{Ce}$ is helpful to reduce grain size through improve the nucleation number of crystallization [13]. The present work was thus to examine such effect with a view of establishing the potential for enhancing the mechanical properties of these alloys.

In order to ensure the low-cycle fatigue behavior and explore the rules and effect of rare earth element $\mathrm{Ce}$ addition on the fatigue behavior of $\mathrm{Al}-4.5 \mathrm{Cu}-0.6 \mathrm{Mg}-0.3 \mathrm{Si}$ alloy, this paper take into consideration the theoretical discussion of the low-cycle fatigue behavior and the damage mechanism in order to improve the fatigue performance of the department alloy and provide reliable theoretical basis for practical application. 


\section{EXPERIMENTAL}

SG-5-10 electrical resistance furnace crucible was used to melt the $99.8 \%$ aluminum ingot, industrially pure $99.9 \% \mathrm{Cu}, 99.8 \% \mathrm{Mg}$, and $\mathrm{Al}-\mathrm{Ce}$ master alloy at $730^{\circ} \mathrm{C}$ respectively and the melt was cast to $\mathrm{Al}-4.5 \mathrm{Cu}-0.6 \mathrm{Mg}$ $0.3 \mathrm{Si}$ and $\mathrm{Al}-4.5 \mathrm{Cu}-0.6 \mathrm{Mg}-0.3 \mathrm{Si}-0.3 \mathrm{Ce}$ alloy in a 130 $\mathrm{mm}$ cube steel mould. The 1250t horizontal extrusion machine was used to hot extrusion for aluminum alloy ingot, the extrusion ratio was 36:1, the extrusion rod processed into fatigue specimen scale with the distance is $6 \mathrm{~mm}$ diameter and gage length of $10 \mathrm{~mm}$, then the T6 treatment to fatigue specimen with solution at $520^{\circ} \mathrm{C}$ for $4 \mathrm{~h}$ and then water cooling, and aging at $180^{\circ} \mathrm{C}$ for $14 \mathrm{~h}$ and then subsequently air cooling.

Low cycle fatigue experiments in the laboratory static pressure air medium under the axial tensile-full reverse total strain amplitude control mode at room temperature with strain ratio of $R e=1$ on the PLD-50 fatigue test machine. The name of the total strain amplitude range $0.4 \%$ to $1.2 \%$ and the frequency was $1 \mathrm{~Hz}$. All fatigue experiments are conducted to the cyclic stress amplitude decreased to $80 \%$ of the peak of stress amplitude in the entire process of fatigue deformation and the cyclic number is defined as the fatigue life. S-3400N scanning electron microscope was used to scanning analysis the fatigue fracture, JEM-2100 transmission electron microscopy was used to observe the microstructure of fatigue deformation zone. The process of TEM sample preparation was as follows: first of all was mechanical thinning, Electrolytic thinning experiment was conducted in the MTP-1 type electro polisher. Electrolyte is $30 \%$ $\mathrm{HNO}_{3}+70 \% \mathrm{CH}_{3} \mathrm{OH}$ (volume fraction) mixture at $30^{\circ} \mathrm{C}$, the voltage was $17 \mathrm{~V}$, electric current was $40 \mathrm{~mA}$.

\section{RESULTS AND DiSCUSSION}

A. Cyclic Stress Response Behavior of Al-4.5Cu-0.6Mg0.3Si(-0.3Ce) Alloys

The cyclic stress response curves of the Al-4.5Cu$0.6 \mathrm{Mg}-0.3 \mathrm{Si}(-0.3 \mathrm{Ce})$ alloys at various total strain amplitudes are shown in Figure 1.As shown in Figure 1(a), the stable cyclic stress response of the $\mathrm{Al}-4.5 \mathrm{Cu}-$ $0.6 \mathrm{Mg}-0.3 \mathrm{Si}$ alloy is noted at the whole fatigue deformation at the total strain amplitude of $0.4 \%$. At the total strain amplitude of $0.5 \% \sim 1.2 \%$, the alloy exhibits the continuous cyclic strain hardening, but the hardening rate decreases significantly at the later stage of fatigue deformation until the fracture. Figure 1(b) comprehensively shows that when plus total strain amplitude is $0.4 \%$ or $0.5 \%$, the $\mathrm{Al}-4.5 \mathrm{Cu}-0.6 \mathrm{Mg}-0.3 \mathrm{Si}$ and $\mathrm{Al}-4.5 \mathrm{Cu}-0.6 \mathrm{Mg}-0.3 \mathrm{Si}-0.3 \mathrm{Ce}$ alloys characterized by cyclic hardening in the early stages of the fatigue deformation, and then show the cycle stability. When plus total strain amplitude is $0.6 \%, 0.8 \%, 1.0 \%$ or $1.2 \%$, Al$4.5 \mathrm{Cu}-0.6 \mathrm{Mg}-0.3 \mathrm{Si}$ and $\mathrm{Al}-4.5 \mathrm{Cu}-0.6 \mathrm{Mg}-0.3 \mathrm{Si}-0.3 \mathrm{Ce}$ alloys characterized by cyclic hardening in the early stages of the fatigue deformation, and then show the cycle softening.
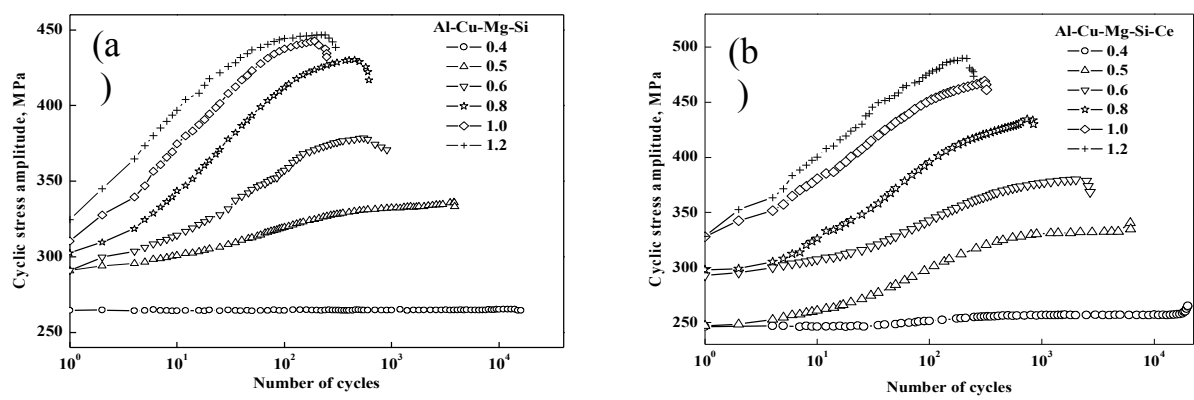

Figure 1. Cyclic stress response curves of extruded $\mathrm{Al}-4.5 \mathrm{Cu}-0.6 \mathrm{Mg}-0.3 \mathrm{Si}(-0.3 \mathrm{Ce})$ alloys with $\mathrm{T} 6$ treatment (a) $\mathrm{Al}-4.5 \mathrm{Cu}-0.6 \mathrm{Mg}-0.3 \mathrm{Si}$ alloy; (b) $\mathrm{Al}-4.5 \mathrm{Cu}-0.6 \mathrm{Mg}-0.3 \mathrm{Si}-\mathrm{Ce}$ alloy

The cyclic stress response curves of $\mathrm{Al}-4.5 \mathrm{Cu}-0.6 \mathrm{Mg}$ $0.3 \mathrm{Si}(-0.3 \mathrm{Ce})$ alloys at various total strain amplitudes are 
illustrated in Figure 2, it can be seen from the graph that the Al-4.5Cu-0.6Mg-0.3Si-0.3Ce alloy exhibits the higher cyclic stress level on the whole fatigue deformation stage under the same plus total strain amplitude. This phenomenon can be explained by that Ce can strengthen the grain boundary, refine and dispersion the strengthening phase of Al-4.5Cu-0.6Mg-0.3Si alloy, so as to improve the cyclic deformation resistance of $\mathrm{Al}-4.5 \mathrm{Cu}-$
0.6Mg-0.3Si alloy. In addition, $\mathrm{Ce}$ can inhibit recrystallization, combined to obtain certain external reinforcement, external toughening effect. Moreover, rare earth element $\mathrm{Ce}$ can form intermetallic compound $\mathrm{Al}_{3} \mathrm{Ce}$ with aluminum. It will increase the stacking fault energy of $\{111\}$ surface, then increase the coplanar slip tendency of $\mathrm{Al}-4.5 \mathrm{Cu}-0.6 \mathrm{Mg}-0.3 \mathrm{Si}$ alloy.
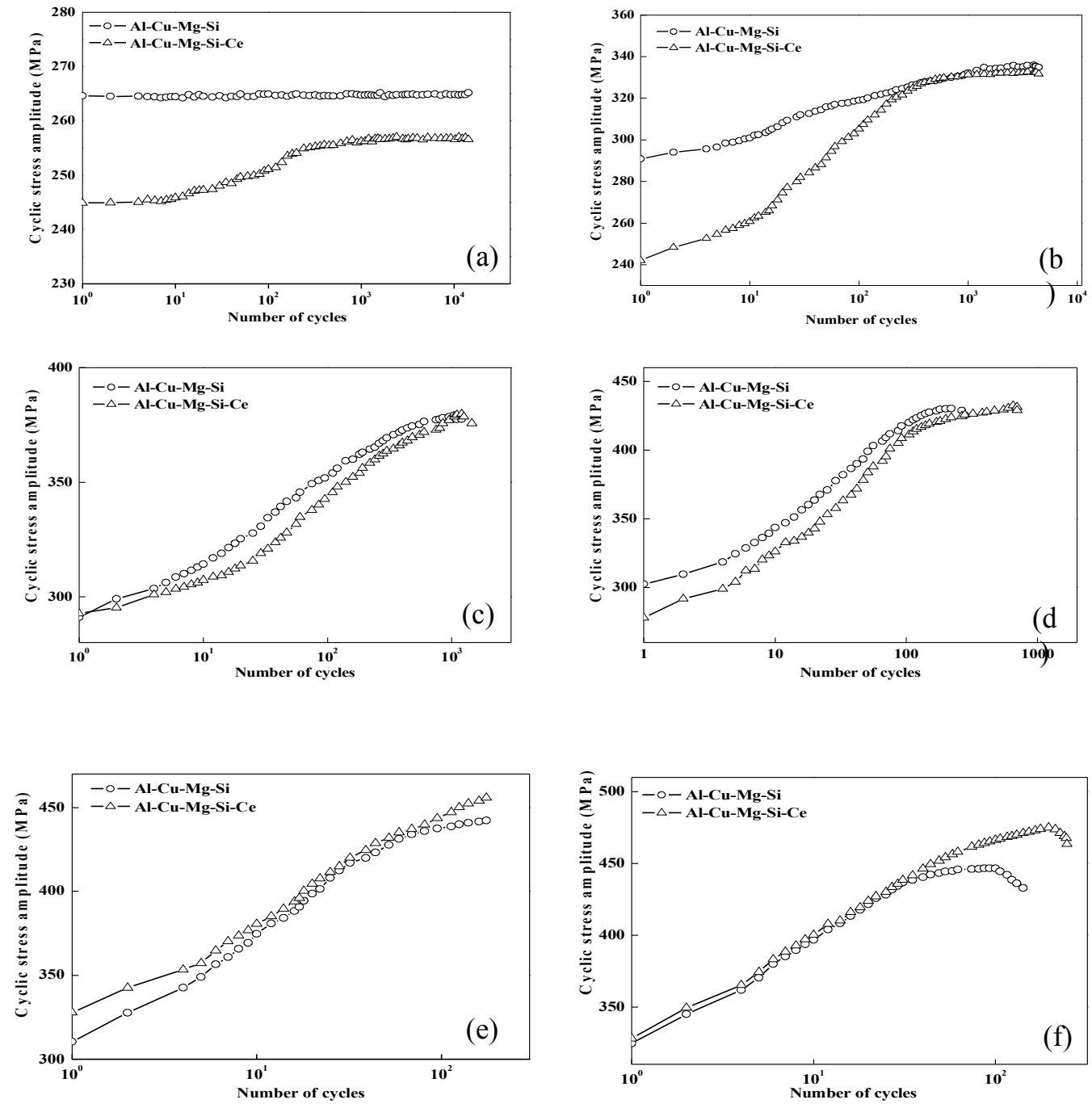

Figure 2. Comparison in cyclic stress response curves for $\mathrm{Al}-4.5 \mathrm{Cu}-0.6 \mathrm{Mg}-0.3 \mathrm{Si}(-0.3 \mathrm{Ce})$ alloys with $\mathrm{T} 6$ treatment

(a) $\Delta \varepsilon \mathrm{t} / 2=0.4 \%$; (b) $\Delta \varepsilon \mathrm{t} / 2=0.5 \%$; (c) $\Delta \varepsilon \mathrm{t} / 2=0.6 \%$; (d) $\Delta \varepsilon \mathrm{t} / 2=0.8 \%$; (e) $\Delta \varepsilon \mathrm{t} / 2=1.0 \%$ (f) $\Delta \varepsilon \mathrm{t} / 2=1.2 \%$

B. Low-fatigue Life Behavior of Al-4.5Cu-0.6Mg-0.3Si($0.3 \mathrm{Ce}$ ) Alloys

The total strain amplitude $\left(\Delta \varepsilon_{t} / 2\right)$ versus fatigue life $\left(N_{f}\right)$ curves for both $\mathrm{Al}-\mathrm{Cu}-\mathrm{Mg}-\mathrm{Si}$ and $\mathrm{Al}-\mathrm{Cu}-\mathrm{Mg}-\mathrm{Si}-\mathrm{Ce}$ alloys with T6 treatment are shown in Figure 3. It is noted that the fatigue life of the Al-Cu-Mg-Si-Ce alloy is higher than that of the $\mathrm{Al}-4.5 \mathrm{Cu}-0.6 \mathrm{Mg}-0.3 \mathrm{Si}$ alloy at various total strain amplitudes. This can be inferred that low cyclic fatigue lives of the $\mathrm{Al}-\mathrm{Cu}-\mathrm{Mg}$ alloy with $\mathrm{T} 6$ treated state is significantly improved when rare earth element $0.3 \% \mathrm{Ce}$ is added. 
Figure 4 show the plastic strain amplitude and elastic strain amplitude versus reversals to failure curves of $\mathrm{Al}$ $4.5 \mathrm{Cu}-0.6 \mathrm{Mg}-0.3 \mathrm{Si}$ and $\mathrm{Al}-4.5 \mathrm{Cu}-0.6 \mathrm{Mg}-0.3 \mathrm{Si}-0.3 \mathrm{Ce}$ alloys.

As seen in Figure 4, the plastic and the elastic strain amplitudes of $\mathrm{Al}-4.5 \mathrm{Cu}-0.6 \mathrm{Mg}-0.3 \mathrm{Si}$ and $\mathrm{Al}-4.5 \mathrm{Cu}-$ $0.6 \mathrm{Mg}-0.3 \mathrm{Si}-0.3 \mathrm{Ce}$ alloys with $\mathrm{T} 6$ treated state as a function of reversals to failure show a linear relationship which are obey Coffin-Manson and Basquin theory.

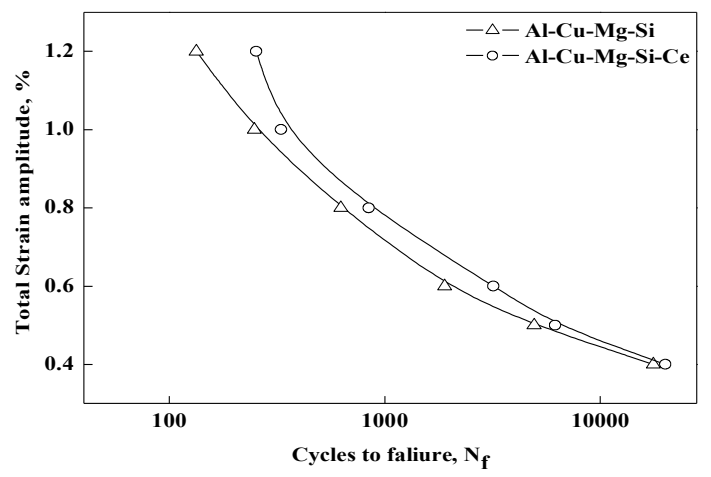

Figure 3. Total strain amplitude versus fatigue life curves for $\mathrm{Al}-4.5 \mathrm{Cu}-0.6 \mathrm{Mg}-0.3 \mathrm{Si}(-0.3 \mathrm{Ce})$ alloys
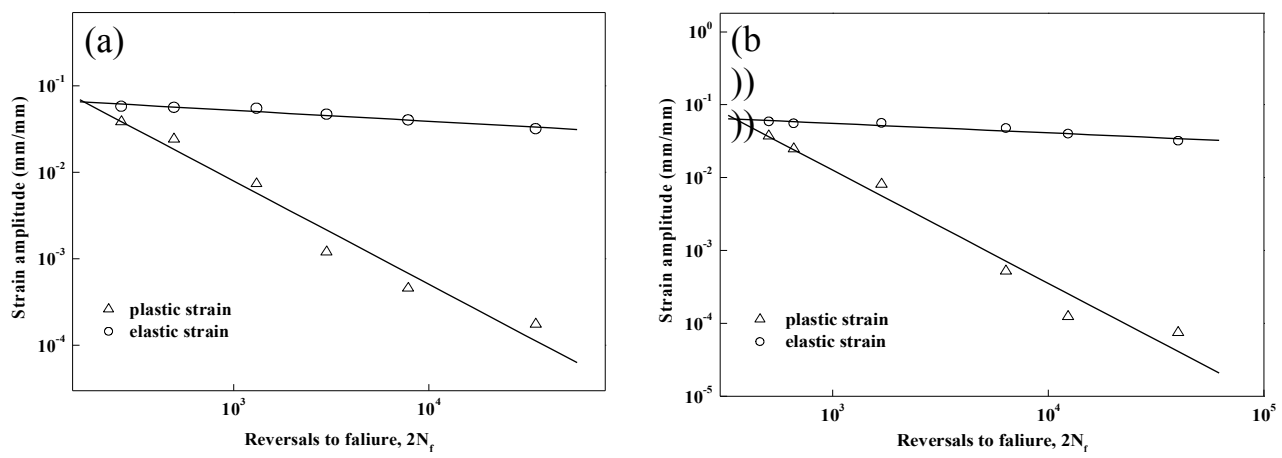

Figure 4. Strain amplitude versus reversals to failure curves of $\mathrm{Al}-4.5 \mathrm{Cu}-0.6 \mathrm{Mg}-0.3 \mathrm{Si}(-0.3 \mathrm{Ce})$ alloys

(a) $\mathrm{Al}-4.5 \mathrm{Cu}-0.6 \mathrm{Mg}-0.3 \mathrm{Si}$ alloy (b) $\mathrm{Al}-4.5 \mathrm{Cu}-0.6 \mathrm{Mg}-0.3 \mathrm{Si}-0.3 \mathrm{Ce}$ alloy

C. Cyclic Stress-strain Behavior of Al-4.5Cu-0.6Mg0.3Si(-0.3Ce) Alloys

The relationship between cyclic stress amplitude and plastic strain amplitude can be expressed by the power law :

$$
\Delta \sigma / 2=K^{\prime}\left(\Delta \varepsilon_{P} / 2\right)^{n^{\prime}}
$$

Where $K^{\prime}$ is the cyclic strength coefficient and $n^{\prime}$ is the cyclic strain-hardening exponent. Cyclic stress versus strain curves for $\mathrm{Al}-4.5 \mathrm{Cu}-0.6 \mathrm{Mg}-0.3 \mathrm{Si}(-0.3 \mathrm{Ce})$ alloys with $\mathrm{T} 6$ state are shown in Figure 5 . For the $\mathrm{Al}-4.5 \mathrm{Cu}-$ $0.6 \mathrm{Mg}-0.3 \mathrm{Si}$ and $\mathrm{Al}-4.5 \mathrm{Cu}-0.6 \mathrm{Mg}-0.3 \mathrm{Si}-0.3 \mathrm{Ce}$ alloys with $\mathrm{T} 6$ treated, the relationship between the plastic strain amplitude and the cyclic stress amplitude is the single slope straight line. They also obey the index relationship in (1), the $K^{\prime}$ and $n^{\prime}$ values of two alloys can be determined by linear regression analysis as shown in Table I. It can be seen from Table I that the Al-4.5Cu$0.6 \mathrm{Mg}-0.3 \mathrm{Si}-0.3 \mathrm{Ce}$ alloy can increase the $K^{\prime}$ and $n^{\prime}$ values compared with the $\mathrm{Al}-4.5 \mathrm{Cu}-0.6 \mathrm{Mg}-0.3 \mathrm{Si}$ alloy. 


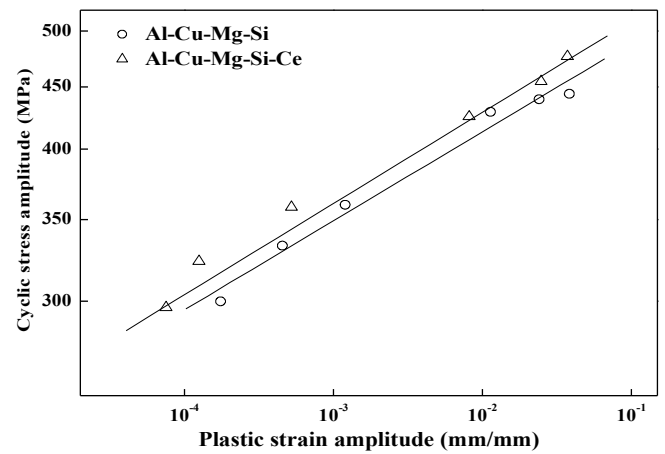

Figure 5. Cyclic stress-strain curves of Al- $4.5 \mathrm{Cu}-0.6 \mathrm{Mg}-0.3 \mathrm{Si}(-0.3 \mathrm{Ce})$ alloys

TABLE I. Strain fatigue Parameters of Al-4.5Cu-0.6Mg-0.3Si AND Al-4.5Cu-0.6Mg-0.3Si-0.3CE ALlOys

\begin{tabular}{|c|c|c|c|c|c|c|}
\hline & $\begin{array}{c}\sigma_{f}^{\prime} \\
(M P a)\end{array}$ & $b$ & $\begin{array}{c}\varepsilon_{f}^{\prime} \\
(\%)\end{array}$ & $c$ & $\begin{array}{c}K^{\prime} \\
(M P a)\end{array}$ & $n^{\prime}$ \\
\hline Al-Cu-Mg-Si alloy & 862.7 & -0.125 & 0.0641 & 1.480 & 578.3 & 0.073 \\
\hline Al-Cu-Mg-Si-Ce alloy & 964.8 & -0.132 & 0.0681 & 2.753 & 605 & 0.075 \\
\hline
\end{tabular}

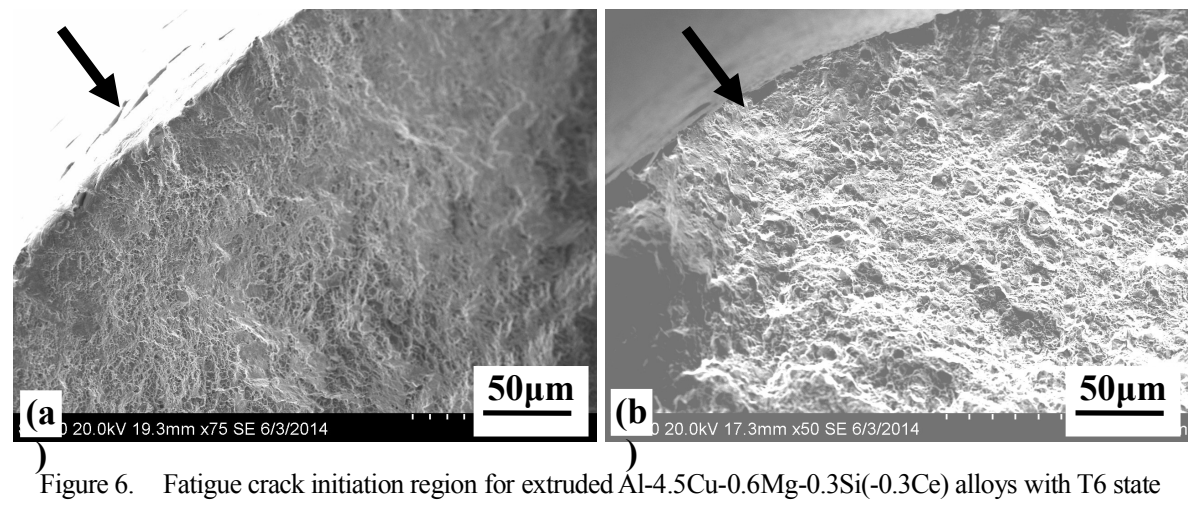

(a) Al-4.5Cu-0.6Mg-0.3Si alloy, $\Delta \varepsilon t / 2=0.8 \%$; (b) Al-4.5Cu-0.6Mg-0.3Si-0.3Ce alloy, $\Delta \varepsilon t / 2=0.8 \%$

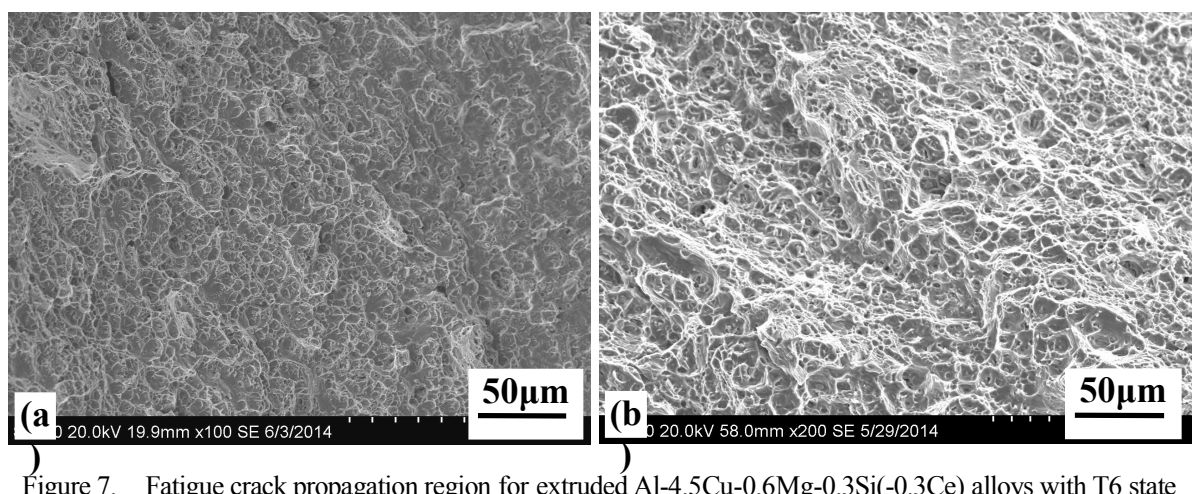

(a) Al-4.5Cu-0.6Mg-0.3Si alloy, $\Delta \varepsilon \mathrm{t} / 2=0.8 \%$; (b) Al- $4.5 \mathrm{Cu}-0.6 \mathrm{Mg}-0.3 \mathrm{Si}-0.3 \mathrm{Ce}$ alloy, $\Delta \varepsilon \mathrm{t} / 2=0.8 \%$

D. Fatigue Fracture of $\mathrm{Al}-4.5 \mathrm{Cu}-0.6 \mathrm{Mg}-0.3 \mathrm{Si}(-0.3 \mathrm{Ce})$ Alloys

Fatigue crack initiation region for extruded $\mathrm{Al}-4.5 \mathrm{Cu}-$ $0.6 \mathrm{Mg}-0.3 \mathrm{Si}(-0.3 \mathrm{Ce})$ alloys under the different plus total strain amplitude with T6 state are shown in Figure 6. The crack initiation in the sample surfaces of $\mathrm{Al}-4.5 \mathrm{Cu}-$ $0.6 \mathrm{Mg}-0.3 \mathrm{Si}(-0.3 \mathrm{Ce})$ alloys are both in a manner of transgranular. 
Fatigue crack propagation region for extruded Al4.5 Cu-0.6Mg-0.3Si $(-0.3 \mathrm{Ce})$ alloys with $\mathrm{T} 6$ state are shown in Figure 7. It can be seen that fatigue crack extend in the form of transgranular in the process of fatigue deformation.

\section{Conclusions}

(1) Under low-cycle fatigue loading condition, the cyclic stress response behaviors of Al- $4.5 \mathrm{Cu}-0.6 \mathrm{Mg}-0.3 \mathrm{Si}$ and $\mathrm{Al}-4.5 \mathrm{Cu}-0.6 \mathrm{Mg}-0.3 \mathrm{Si}-0.3 \mathrm{Ce}$ alloys mainly exhibit exhibit the cyclic strain hardening and cycle stability, the cyclic deformation resistance of $\mathrm{Al}-4.5 \mathrm{Cu}-0.6 \mathrm{Mg}-0.3 \mathrm{Si}$ alloy with $\mathrm{T} 6$ treated state is significantly improved when Ce is added.

(2) When the total strain amplitudes various from $0.4 \% \sim 1.2 \%$, the cyclic deformation resistance of $\mathrm{Al}-$ $4.5 \mathrm{Cu}-0.6 \mathrm{Mg}-0.3 \mathrm{Si}-0.3 \mathrm{Ce}$ alloy is higher than the $\mathrm{Al}-$ $4.5 \mathrm{Cu}-0.6 \mathrm{Mg}-0.3 \mathrm{Si}$ alloy.

(3) The plastic strain amplitude and elastic strain amplitude with reversals to failure of $\mathrm{Al}-4.5 \mathrm{Cu}-0.6 \mathrm{Mg}$ $0.3 \mathrm{Si}$ and $\mathrm{Al}-4.5 \mathrm{Cu}-0.6 \mathrm{Mg}-0.3 \mathrm{Si}-0.3 \mathrm{Ce}$ alloys follow the Coffin-Manson and Basquin laws.

(4) Under the condition of low cycle fatigue loading, the fatigue crack initiation of $\mathrm{Al}-4.5 \mathrm{Cu}-0.6 \mathrm{Mg}-0.3 \mathrm{Si}(-$ $0.3 \mathrm{Ce}$ ) alloys in both in a transgranular manner and extension in a transgranular manner the surface of the sample.

\section{REFERENCES}

[1] R. Sadeler and M. Ocal, "Influence of relative slip on fretting fatigue behaviour of 2014 aluminium alloy with the age-hardened conditions T4 and T6," Metals and Materials International, Vol. 18, 2012, pp. 273-277.

[2] Y. B. Liu, Z. Y. Liu, Y. T. Li, Q. K. Xia and J. Zhou, "Enhanced fatigue crack propagation resistance of an $\mathrm{Al}-\mathrm{Cu}-\mathrm{Mg}$ alloy by artificial aging," Materials Science and Engineering A, Vol. 492, 2008, pp. 333-336.

[3] M. Z. Zhou, D. Q. Yi, W. J. Liu, W. J. Liu and F. Zheng, "Enhanced fatigue crack propagation resistance of an $\mathrm{Al}-\mathrm{Cu}-\mathrm{Mg}$ alloy by artificial aging under influence of electrical field," Materials
Science and Engineering A, Vol. 527, 2010, pp. 4070-4075.

[4] E. Lertora, and C. Gambaro, "AA8090 Al-Li alloy FSW parameters to minimize defects and increase fatigue life," International Journal of Material Forming, Vol. 3, 2010, pp. 1003-1006.

[5] A. A. Luo, R. C. Kubic and J. M. Tartaglia, "Microstructure and fatigue properties of hydroformed aluminum alloys 6063 and 5754," Metallurgical and Materials Transactions A, Vol. 34, 2003, pp. 2549 2557.

[6] T. W. Zha, J. X. Zhang and Y. Y. Jiang, "A study of fatigue crack growth of 7075-T651 aluminum alloy," International Journal of Fatigue, Vol. 30, 2008, pp. 1169 1180.

[7] Z. M. Yin, Q. L. Pan, Y. H. Zhang and F. Jiang, "Effect of minor Sc and $\mathrm{Zr}$ on the microstructure and mechanical properties of $\mathrm{Al}-\mathrm{Mg}$ based alloys," Materials Science and Engineering A, Vol. 208, 2000, pp. 151-154.

[8] V. Raghavan, "Al-Ce-Nd(Aluminum-Cerium-Neodymium)," Journal of phase Equilibria and Diffusion, Vol. 28, 2007, pp. 542543.

[9] M. Song, D. H. Xiao and F. Q. Zhang, "Effect of Ce on the thermal stability of the $\Omega$ phase in an Al-Cu-Mg-Ag alloy," Rare Metals, Vol. 28, 2009, pp. 156-159.

[10]M. Hosseinifar and D. V. Malakhov, "Effect of Ce and La on microstructure and properties of a 6xxx series type aluminum alloy,” Journal of Materials Science, Vol. 43, 2008, pp. 7157-7164.

[11]A. A. Alan, W. Y. Luo, R. K. Wu, L. Jin, A. K. Sachdev, et al, "Microstructure and Mechanical Properties of Extruded Magnesium-Aluminum-Cerium Alloy Tubes," Metallurgical and Materials Transactions A, Vol.41A, 2010, pp. 2662-2674.

[12]J. P. Lai, R. P. Jiang, H. S. Liu, X. X. Dun, Y. F. Fen, et al, "Influence of cerium on microstructures and mechanical properties of Al-Zn-Mg-Cu alloys,” Journal of Central South University. Vol. 19, 2012, pp. 869-974.

[13]A. K. Chaubey, S. Mohapatra, K. Jayasankar, S. K. Prahan, B. Satpati, et al, "Effect of cerium addition on microstructure and mechanical properties of $\mathrm{Al}-\mathrm{Zn}-\mathrm{Mg}-\mathrm{Cu}$ alloy," Transactions of the Indian Institute of Metals, Vol. 62, 2009, pp. 539-543. 